\title{
EFISIENSI, EFEKTIVITAS DAN KONTRIBUSI SUB PAJAK DAERAH DI KABUPATEN MALUKU TENGGARA BARAT
}

\author{
Paulus Leliak, Gatot Sasongko ${ }^{2}$ \\ ${ }^{1}$ Fakultas Pascasarjana Interdisiplin, Universitas Kristen Satya Wacana, Indonesia \\ ${ }^{2}$ Fakultas Ekonomika dan Bisnis, Universitas Kristen Satya Wacana, Indonesia \\ 1092017001@student.uksw.edu, ${ }^{2}$ gatot.sasongko@ @staff.uksw.edu
}

\begin{abstract}
The purpose of this study was to determine the efficiency of local tax revenues, the contribution of sub-regional taxes to local taxes, the effectiveness of local tax revenues and sub-regional taxes. The research method is quantitative descriptive with secondary data from the Regional Revenue Agency in West Southeast Maluku Regency, West Southeast Maluku District Financial and Asset Management Agency and the Directorate General of Fiscal Balance of the Ministry of Finance of the Republic of Indonesia in 2012 - 2016. The result is inefficiencies in tax collection area. The highest sub-regional tax contributions are taxes on non-metal minerals and rocks, under restaurant tax and street lighting taxes. Regional tax effectiveness is categorized as less effective. The effectiveness of regional sub-tax namely hotel tax and tax on non-metal minerals and rocks is categorized as very effective; advertisement tax, street lighting tax and acquisition fee for land and building rights are categorized as quite effective; advertisement tax, entertainment tax and rural and urban land and building tax are categorized as ineffective.
\end{abstract}

Keywords: West Southeast Maluku, Sub Regional Taxes, Efficiency, Contributions, Effectiveness

\begin{abstract}
ABSTRAK
Tujuan penelitian ini untuk mengetahui efisiensi penerimaan pajak daerah, kontribusi sub pajak daerah terhadap pajak daerah, efektivitas penerimaan pajak daerah dan sub pajak daerah. Metode penelitian adalah kuantitatif deskriptif dengan data sekunderdari Badan Pendapatan Daerah Kabupaten Maluku Tenggara Barat, Badan Pengelolaan Keuangan dan Asset Daerah Kabupaten Maluku Tenggara Barat dan Direktorat Jenderal Perimbangan Keuangan Kementerian Keuangan Republik Indonesia tahun 2012 - 2016. Hasilnya adalah efisiensi pemungutan pajak daerah tidak efisien, kontribusi sub pajak daerah tertinggi adalah pajak mineral bukan logam dan batuan, dibawahnya pajak restoran dan pajak penerangan jalan. Efektivitas pajak daerah dikategorikankurang efektif. Efektivitas sub pajak daerah yaitu pajak hotel dan pajak mineral bukan logam dan batuan dikategorikan sangat efektif; pajak reklame, pajak penerangan jalan dan bea perolehan hak atas tanah dan bangunan dikategorikan cukup efektif; pajak reklame, pajak hiburan dan pajak bumi dan bangunan perdesaan dan perkotaan dikategorikan tidak efektif.
\end{abstract}

Kata kunci:Maluku Tenggara Barat, Sub Pajak Daerah, Efisiensi, Kontribusi, Efektivitas 
Otonomi daerah merupakan sebuah keniscayaan karena dengan lahirnya otonomi daerah maka setiap daerah diberikan keleluasaan untuk melaksanakan kewenangannya guna mengurus atau mengatur rumah tangganya sendiri baik itu urusan pemerintahan maupun urusan pelayanan publik atas dasar prakarsa, kreativitas dan peran serta aktif masyarakat dalam rangka memajukan dan mengembangkan daerahnya.

Melalui Undang-undang Nomor 9 Tahun 2015 Tentang Perubahan Kedua Atas Undang-undang Nomor 23 Tahun 2014 Tentang Pemerintahan Daerah, dimanaPemerintah Daerah diberikan kewenangan yang seluas-luasnya untuk menggali sumber-sumber pendanaan untuk membiayai pelaksanaan pembangunan dengan memanfaatkan pengelolaan sumber daya dan potensi yang dimiliki daerah yang bisa dijadikansebagai potensi atau sumber pendapatan daerah sehingga akan mengurangi tingkat ketergantungan daerah otonom terhadap sumber-sumber keuangan dari Pemerintah Pusat.Dengan semakin berkurangnya tingkat ketergantungan daerah otonom terhadap bantuan keuangan Pemerintah Pusat, akan semakin berdampak positif bagi kinerja Pemerintah Daerah karena dianggap mandiri dalam pembiayaan dan pelaksanaan pembangunan daerah.Kemandirian daerah akan tercapai melalui intensifikasi dan ekstensifikasi pajak daerah, retribusi daerah, laba Badan Usaha Milik Daerah (BUMD) dan lain-lain pendapatan asli daerah yang sah. Daerah yang mandiri akan mampu melaksanakan pembangunan daerah dengan baik sehingga akan meningkatkan kesejahteraan masyarakat. Kesejahteraan masyarakat yang meningkat dapat dilihat dari rendahnya angka kemiskinan, rendahnya angka pengangguran dan meningkatnya daya beli masyarakat.

Kabupaten Maluku Tenggara Barat merupakan salah satu kabupaten pemekaran di Propinsi Maluku yang masih terus menyelenggarakan pemerintahan dan pembangunan guna menciptakan keadilan sosial bagi seluruh masyarakatnya.Untuk merealisasikan program dan kegiatan yang telah ditetapkan tentu dibutuhkan pendanaan yang baik dan tersedia dalam jumlah yang cukup disamping itu harus berasal dari kemampuan dan kekuatannya sendiri.

Berikut adalah data realisasi Pendapatan Asli Daerah Kabupaten Maluku Tenggara Barat :

Tabel 1

Data Realisasi Pendapatan Asli Daerah (PAD)Kabupaten Maluku Tenggara Barat Tahun 2012-2016

\begin{tabular}{c|c|c|c|c|c}
\hline \multirow{2}{*}{ No } & \multirow{2}{*}{ Tahun } & \multicolumn{2}{|c|}{ Komponen Pendapatan Asli Daerah (PAD) } & \multirow{2}{*}{ Total } \\
\cline { 3 - 5 } & & $\begin{array}{c}\text { Pajak Daerah } \\
\text { (Rp) }\end{array}$ & $\begin{array}{c}\text { Retribusi } \\
\text { Daerah (Rp) }\end{array}$ & $\begin{array}{c}\text { Lain-lain PAD } \\
\text { Yang Sah (Rp) }\end{array}$ & \\
\hline 1 & 2012 & 2.508 .000 .707 & 3.079 .040 .433 & 6.729 .210 .118 & $\mathbf{1 2 . 3 1 6 . 2 5 1 . 2 5 8}$ \\
2 & 2013 & 3.449 .307 .484 & 3.176 .015 .843 & 11.535 .291 .507 & $\mathbf{1 8 . 1 6 0 . 6 1 4 . 8 3 4}$ \\
3 & 2014 & 5.056 .455 .794 & 3.180 .631 .854 & 10.963 .189 .318 & $\mathbf{1 9 . 2 0 0 . 2 7 6 . 9 6 6}$ \\
4 & 2015 & 5.825 .614 .778 & 3.078 .549 .613 & 16.645 .535 .451 & $\mathbf{2 5 . 5 4 9 . 6 9 9 . 8 4 2}$ \\
5 & 2016 & 7.829 .991 .234 & 4.080 .033 .278 & 16.914 .471 .448 & $\mathbf{2 8 . 8 2 4 . 4 9 5 . 9 6 0}$ \\
\hline
\end{tabular}

Sumber :Badan Pendapatan Daerah Kab. MTB., Badan Pengelolaan Keuangan dan Asset Daerah Kab. MTB.dan Ditjen. Perimbangan Keuangan Kemenkeu RI. (2017). 
Berdasarkan tabel 1, terlihat bahwa realisasi pendapatan asli daerah lebih besar disumbangkan lain-lain pendapatan asli daerah yang sah setelah itu pajak daerah kemudian retribusi daerah.Sesuai tabel diatas maka penulis lebih tertarik meneliti tentangpajak daerah karena pajak daerah memiliki peningkatan lebih tinggi yaitu sebesar 3 (tiga) kali lipat bila dibandingkan dengan sumber pendapatan yang lain.

Pajak merupakan salah satu kewajiban masyarakat dalam menunjang pembangunan didaerahnya selain itu dengan membayar pajak merupakan bukti atau wujud partisipasi masyarakat dalam proses pembangunan didaerah, olehnya itu aparatur pemerintah pengelola pajak sudah seharusnya jujur dalam mengelola uang rakyat ini. Berikut ini ditampilkan data target dan realisasi pajak daerah di Kabupaten Maluku Tenggara Barat dari tahun 2012 - 2016

Tabel 2

Data Target dan Realisasi Pajak DaerahKabupaten Maluku Tenggara Barat

\begin{tabular}{c|c|c|c}
\multicolumn{5}{c}{ Tahun 2012-2016 } \\
\hline No & Tahun & Target (Rp) & Realisasi (Rp) \\
\hline 1 & 2012 & 3.986 .256 .070 & 2.508 .000 .707 \\
2 & 2013 & 4.328 .921 .800 & 3.449 .307 .484 \\
3 & 2014 & 3.904 .700 .510 & 5.056 .455 .794 \\
4 & 2015 & 6.665 .640 .612 & 5.825 .614 .778 \\
5 & 2016 & 9.907 .280 .000 & 7.829 .991 .234 \\
\hline \multicolumn{4}{l}{ Sumber : Badan Pendapatan Daerah Kab. MTB. Badan Pengelolaan Keuangan dan Asset Daerah Kab. }
\end{tabular}

MTB. dan Ditjen. Perimbangan KeuanganKemenkeu RI. (2017).

Dari tabel 2.terlihat realisasi pajak daerah berfluktuasi danlebih didominasi oleh tidak tercapainya target yang telah ditetapkan karena penetapan target yang terlalu besar. Hanya tahun tahun 2014 yang berhasil melebihi target yang telah ditetapkan. Hal ini menunjukan bahwa penetapan target oleh pemerintah daerah tidak dilakukan dengan perhitungan yang baik dan akurat serta tidak pernah didasarkan pada nilai realisasi tahun sebelumnya.

Penelitian tentang pajak daerah dan retribusi daerah sebagai sumber pendapatan asli daerah telah dilakukan oleh beberapa peneliti sebelumnya yaituYaneka Julistiana et al (2012)dan Avian Nur Andianto et al (2017), hasil penelitiannya adalahrasio efisiensinya dikategorikan sangat efisien dan rasio efektifitasnya dikategorikan sangat efektif. Persamaan dari kedua penelitian ini yaitu sama-sama meneliti tentang pajak daerah dan retribusi daerah dengan alat analisis yang sama pula yaitu rasio efektifitas dan rasio efisiensi. Sedangkan perbedaannya dari kedua penelitian ini yaitu Yaneka Julistiana et al (2012) meneliti tentang pendapatan asli daerah sedangkan Avian Nur Andianto et al (2017) penerimaan pajak daerah. Namunkelemahan dari kedua penelitian diatas yaitu mereka tidak fokus selain itu alat analisis yang digunakan hanya 2 (dua) alat analisis yaitu rasio efektifitas dan rasio efisiensi sehingga kajian lebih mendalam dengan menggunakan alat analisis derajat kontribusi belum digunakan. 
Penelitian lebih lanjut dengan menggunakan alat analisis derajat kontribusi, rasio efektifitas dan rasio efisiensi telah dilakukan oleh Devy Octaviana S. (2103), Martha M. Koibur (2015), Ryfal Yoduke et al (2015), I Gede Oka Dhananjaya B. (2015), Zainuddin (2016), Ismiranti M. Putri (2016), hasil penelitian dari para peneliti tersebut menunjukan bahwa rasio efektifitasnya dikategorikan efektiff, rasio efisiensinya dikategorikan sudah efisien dan derajat kontribusinya dikategorikan sangat berkontribusi. Persamaan dari penelitian-penelitian ini yaitu sama-sama meneliti tentang pajak daerah dan retribusi daerah sebagai sumber pendapatan asli daerah dengan alat analisis yang sama pula yaitu rasio efektifitas, rasio efisiensi dan derajat kontribusi. Tetapi kekurangan dari penelitian mereka yaitu cakupannya masih terlalu global atau bersifat umum karena belum fokus untuk meneliti secara mendalam tentang sub pajak daerah.

Penelitian tentang sub pajak daerah telah dilakukan oleh Pratiwi DK (2002), Ira Hardiana Kusuma W. (2005), Ratih U. Hidayanti (2008), Reza Arditia (2012), H. Mat Juri (2012), Raymond R. Korengkeng (2017), I Nyoman Sutama et al (2017). Hasil penelitiannya adalah kontribusi sub pajak daerah selalu berfluktuasi, rasio efektifitasnya dikategorikan sudah efektif dan rasio efisiensinya dikategorikan sangat efisien. Persamaan dari penelitian ini adalah sama-sama meneliti sub pajak daerah dengan menggunakan alat analisis yang sama pula yaitu alat analisis derajat kontribusi, rasio efektifitas dan rasio efisiensi. Sedangkan perbedaannya terletak pada lokasi dan waktu penelitian. Kelemahan dalam penelitian ini adalah mereka belum meneliti secara mendalam semua sub pajak daerah sehingga kajian lebih mendalam dan lebih fokus tentang sub pajak daerah akan dilakukan oleh penulis dengan menggunakan alat analisis derajat kontribusi, rasio efektifitas dan rasio efisiensi.

Yang menjadi tujuan dari penelitian ini adalah untuk menganalisis rasio efisiensi pemungutan pajak daerah, derajat kontribusisub pajak daerah serta rasio efektifitaspajak daerah dan sub pajak daerah di Kabupaten Maluku Tenggara Barat.

\section{KAJIAN TEORITIS}

\section{Pengertian Anggaran Pendapatan dan Belanja Daerah (APBD).}

Pada Bab I pasal 1 ayat 9 Peraturan Menteri Dalam Negeri No. 21 Tahun 2011Tentang Perubahan Kedua Atas Peraturan Menteri Dalam Negeri No. 13 Tahun 2006 Tentang Pedoman Pengelolaan Keuangan Daerah(www.keuda.kemendagri.go.id), mendefenisikan Anggaran Pendapatan dan Belanja Daerah (APBD) adalah rencana keuangan tahunan pemerintahan daerah yang dibahas dan disetujui bersama oleh Pemerintah Daerah dan Dewan Perwakilan Rakyat Daerah (DPRD), dan ditetapkan dengan Peraturan Daerah. Dengan demikian Anggaran Pendapatan dan Belanja Daerah (APBD) merupakan alat atau wadah 
untuk menampung berbagai kepentingan publik yang diwujudkan melalui berbagai kegiatan dan program dimana pada saat tertentu manfaatnya benar-benar akan dirasakan oleh masyarakat.

Menurut Prof. Dr. Wempy Banga, M. Si (2017:56) Anggaran Pendapatan dan Belanja Daerah (APBD) dapat diartikan sebagai renana kerja pemerintah daerah yang mengandung dua hal, pertama sebagai suatu rencana kerja keuangan yang didalamnya mengandung angkaangka atau jumlah rupiah yang diperlukan dalam rangka mewujudkan tujuan dan sasaran penyelenggaraan pemerintah dan pembangunan daerah. Kedua sebagai suatu renana kerja fisik dan non fisik yang akan dilaksanakan sebagai upaya mewujudkan pelayanan publik didaerah, khususnya bidang ekonomi dan sosial, budaya, politik dan keamanan.

Karena Anggaran Pendapatan dan Belanja Daerah (APBD) merupakan rencana kerja pemerintah daerah maka sudah tentu diharapkan akan memberikan dampak yang baik ketika pelaksanaannya sehingga apa yang menjadi fungsi dari anggaran pendapatan dan belanja daerah itu dapat terjawab karena secara teknis Anggaran Pendapatan dan Belanja Daerah (APBD) ini mencakup dua hal yaitu untuk memprediksi masa depan serta mengevaluasi masa lampau.

\section{Sumber Pendapatan Daerah}

Pada Bab I pasal 1 ayat 50 Peraturan Menteri Dalam Negeri No. 21 Tahun 2011 Tentang Perubahan Kedua Atas Peraturan Menteri Dalam Negeri No. 13 Tahun 2006 Tentang Pedoman Pengelolaan Keuangan Daerah(www.keuda.kemendagri.go.id), menyatakan bahwa pendapatan daerah adalah hak pemerintah daerah yang diakui sebagai penambah nilai kekayaan bersih. Selanjutnya pada pasal 25 pendapatan daerah dikelompokan atas :

1. Pendapatan Asli Daerah (PAD)

2. Dana Perimbangan

3. Lain - lain penerimaan yang sah

Untuk menunjang pembangunan nasional maka sudah tentu pembangunan di setiap daerah mestinya didorong bahkan terus digalakan. Tujuannya sudah tentu untuk memberikan kesejahteraan bagi masyarakat di daerah setempat. Dalam pelaksanaan pembangunan di daerah tentunya daerah membutuhkan anggaran yang tidak sedikit jumlahnya. Kondisi inilah yang mendorong pemerintah daerah untuk selalu kreatif dan inovatif dalam mencari sumber sumber pendanaan sehingga ketergantungan terhadap pemerintah pusat dapat dikurangi. Sejalan dengan hal ini maka pemerintah pusat telah membuka ruang yang sebesar-besarnya melalui kewenangan yang telah diberikan oleh undang-undang kepada pemerintah daerah guna melakukan ekstensifikasi dan intensifikasi sumber - sumber keuangannya. Salah satu 
sumber pendapatan daerah adalah pendapatan asli daerah yang merupakan pendapatan yang bersumber dari kekayaan daerah setempat.

\section{Pajak Daerah}

Menurut Undang-undang Nomor 28 Tahun 2009 Tentang Pajak Daerah dan Retribusi Daerah (www.djpk.depkeu.go.id) menjelaskan bahwa Pajak Daerah yang selanjutnya disebut Pajak, adalah kontribusi wajib kepada daerah yang terutang oleh orang pribadi atau badan yang bersifat memaksa berdasarkan Undang-undang, dengan tidak mendapatkan imbalan secara langsung dan digunakan untuk keperluan daerah bagi sebesar-besarnya kemakmuran rakyat.

Berdasarkan Undang-undang Nomor 28 Tahun 2009 Tentang Pajak Daerah dan Retribusi Daerah( $\underline{w w w . d j p k . d e p k e u . g o . i d})$ maka pajak daerah harus ditetapkan dengan peraturan daerah dan tidak boleh bertentangan dengan peraturan-peraturan perundangundangan serta kebijakan pemerintah pusat.

Pajak daerah memiliki ciri-ciri sebagai berikut :

1. Pajak daerah yang berasal dari pajak Negara yang diserahkan kepada daerah.

2. Penyerahannya berdasarkan Undang-undang.

3. Pajak daerah dipungut oleh daerah berdasarkan undangundang dan aturan hukum lainnya.

4. Hasil pungutan pajak daerah dipergunakan untuk membiayai penyelenggaraan pemerintahan daerah dan pembangunan daerah.

Menurut Undang-undang Nomor 28 Tahun 2009 Tentang Pajak Daerah dan Retribusi Daerah, maka pajak daerah ( $\underline{w w w . d j p k . d e p k e u . g o . i d}$ ) yang menjadi kewenangan pemerintah kabupaten/kota adalah Pajak Hotel, Pajak Restoran, Pajak Hiburan, Pajak Reklame, Pajak Penerangan Jalan, Pajak Mineral Bukan Logam dan Batuan, Pajak Parkir, Pajak Air Tanah, Pajak Sarang Burung Walet, Pajak Bumi dan Bangunan Perdesaan dan Perkotaan dan Bea Perolehan Hak atas Tanah dan Bangunan.

\section{Pengertian Rasio Efisiensi}

Rasio efisiensi menurut Mahmudi, SE., M.Si (2010) adalah ukuran untuk mengukur kinerja pemerintah daerah dalam memobilisasi sumber daya dalam memaksimalkan penerimaan pajak daerah. Rasio ini dihitung dengan cara membandingkan biaya yang dikeluarkan untuk memperoleh pajak daerah dengan realisasi penerimaan pajak daerah.

\section{Pengertian Derajat Kontribusi}

Derajat kontribusi menurut Mahmudi, SE., M.Si (2010) adalah sumbangan sub pajak daerah terhadap total pajak daerah. Derajat kontribusi ini dipergunakan untuk menganalisis tingkat kontribusi sub pajak daerah dalam mendukung pajak daerah. Dalam penelitian ini 
derajat kontribusi dipakai untuk mengetahui atau mengukur sumbangsih atau kontribusisub pajak daerah terhadap pajak daerah di Kabupaten Maluku Tenggara Barat.

\section{Pengertian Rasio Efektifitas}

Rasio efektifitas menurut Mahmudi, SE., M.Si (2010)menunjukan kemampuan pemerintah daerah dalam mengumpulkan pajak daerah dan sub pajak daerah sesuai dengan jumlah penerimaan pajak daerah dan sub pajak daerah yang ditargetkan.Rasio ini dihitung dengan cara membandingkan realisasi dengan target.Rasio efektifitas bertujuan untuk menggambarkan kemampuan Pemerintah Kabupaten dalam memungut sub pajak daerah dalam mendukung pelaksanaan otonomi daerah.

\section{METODE PENELITIAN}

Metode penelitian yang digunakan dalam penelitian ini adalah penelitian deskriptif kuantitatif. Artinya metode penelitian dimana peneliti akan menggambarkan atau menjelaskan penemuan yang terjadi dari penelitian yang dilakukan. (I Nyoman et all, 2017). Data yang digunakan dalam penelitian ini adalah data primer dan datasekunder dan metode analisis data yang digunakan adalah alat analisis derajat kontribusi, rasio efektifitas dan rasio efisiensi.

\section{Alat Analisis}

\section{Rasio Efisiensi Pemungutan Pajak Daerah}

Skema rasio efisiensi pemungutan pajak daerah dapat memberikan gambaran keberhasilan pemerintah daerah dalam menggunakan anggaran untuk membiayai program dan kegiatan yang berkaitan dengan pemungutan pajak daerah.

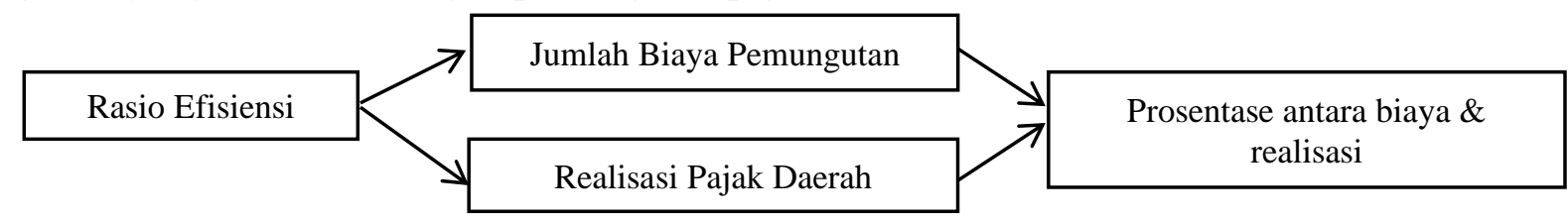

Menurut Mahmudi, SE., M.Si (2010). Untuk menghitung rasio efisiensi digunakan rumus:

Rasio Efisiensi Pajak Daerah ${ }_{n}$

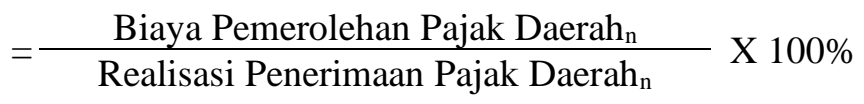

Semakin kecil nilai rasio ini maka semakin efisien kinerja Pemerintah Daerah dalam melakukan pemungutan pajak daerah. Untuk menilai rasio efisiensi pemungutan pajak daerah maka dapat dikategorikan sebagai berikut :

Tabel 3.Klasifikasi Rasio Efisiensi

\begin{tabular}{c|c}
\hline Presentase & Kriteria \\
\hline$<10 \%$ & Sangat Efisien \\
$10 \%-20 \%$ & Efisien \\
$21 \%-30 \%$ & Cukup Efisien \\
$31 \%-40 \%$ & Kurang Efisien \\
$>40 \%$ & Tidak Efisien \\
\hline
\end{tabular}




\section{Derajat Kontribusi Sub Pajak Daerah}

Skema derajat kontribusi menunjukan peran sub pajak daerah terhadap total pendapatan daerah yang memberikan gambaran kontribusi atau sumbangan sub pajak daerah terhadap pajak daerah.

Derajat Kontribusi Sub Pajak Daerah

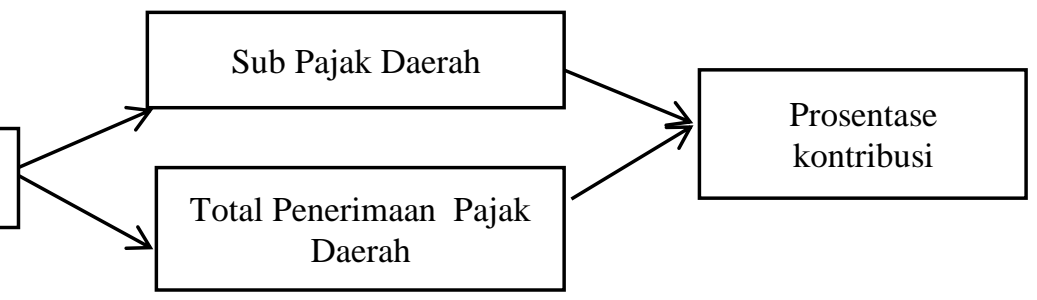

Menurut Mahmudi, SE., M.Si (2010), rumus derajat kontribusi sub pajak daerah adalah :

Derajat Kontribusi Sub Pajak Daerah $_{n} \quad=\frac{\text { Penerimaan Sub Pajak Daerah }_{n}}{\text { Total Penerimaan Pajak Daerah }_{n}} \times 100 \%$

\section{Rasio Efektifitas}

- Rasio Efektifitas Pajak Daerah

Skema rasio efektifitas pemungutan pajak daerah dapat memberikan gambaran kinerja pemerintah daerah dalam merealisasikan pungutan pajak daerah terhadap target yang telah dtetapkan sebelumnya.

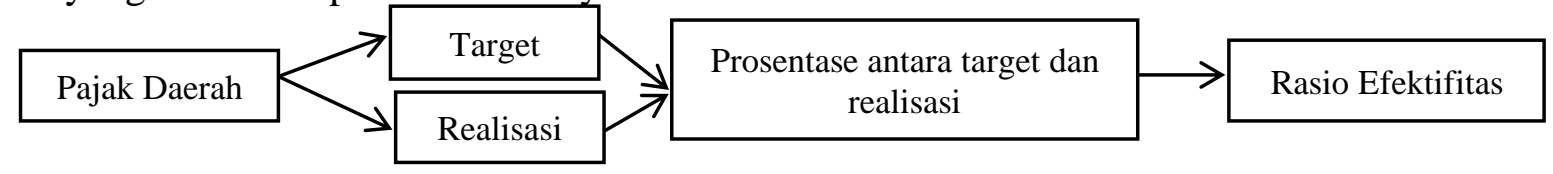

Menurut Mahmudi, SE., M.Si (2010). Untuk menghitung rasio efektifitas digunakan rumus :

$$
\text { Rasio Efektifitas Pajak Daerah }{ }_{n} \quad=\frac{\text { Realisasi Penerimaan Pajak Daerah }_{n}}{\text { Target Penerimaan Pajak Daerah }} \text { X 100\% }_{n}
$$

\section{- Rasio Efektifitas Sub Pajak Daerah}

Skema rasio efektifitas pemungutan sub pajak daerah dapat memberikan gambaran kinerja pemerintah daerah dalam merealisasikan pungutan sub pajak daerah terhadap target yang telah dtetapkan sebelumnya.

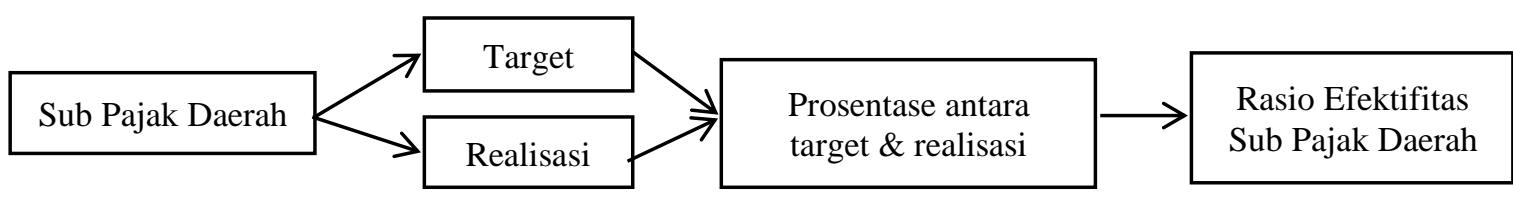

Menurut Mahmudi, SE., M.Si (2010). Untuk menghitung rasio efektifitas digunakan rumus :

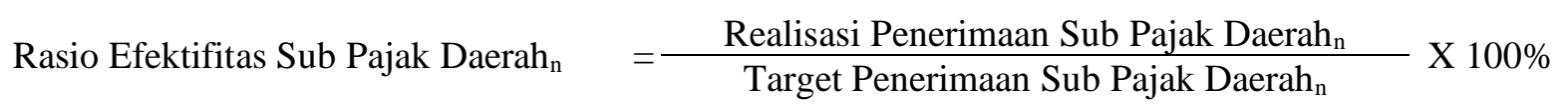


Untuk menilai rasio efektifitas pajak daerah dan sub pajak daerah diklasifikasimenjadi kategori sebagai berikut :

Tabel 4.

Klasifikasi Rasio Efektifitas

\begin{tabular}{c|c}
\hline Presentase & Kriteria \\
\hline$>100 \%$ & Sangat Efektif \\
$100 \%$ & Efektif \\
$90 \%-99 \%$ & Cukup Efektif \\
$75 \%-89 \%$ & Kurang Efektif \\
$<75 \%$ & Tidak Efektif \\
\hline Sumber : Mahmudi, 2010
\end{tabular}

\section{PEMBAHASAN}

\section{Efisiensi Pemungutan Pajak Daerah}

Dalam menjalankan roda pemerintahan tentunya pimpinan atau kepala daerah dituntut untuk dapat melaksanakan setiap program dan kegiatan dengan se-efisien mungkin. Untuk mengetahui suatu program atau kegiatan pemerintah daerah sudah efisien atau belum dapat digunakan rasio efisiensi. Berikut ini akan dilihat tabel efisiensi pemungutan pajak daerah:

Tabel 5

Efisiensi Pemungutan Pajak Daerah Kabupaten Maluku Tenggara Barat

\begin{tabular}{c|c|c|c|c|c}
\multicolumn{7}{c}{ Tahun $2012-2016$} \\
\hline \multirow{2}{*}{ No } & Tahun & $\begin{array}{c}\text { Anggaran } \\
(\mathbf{R p})\end{array}$ & $\begin{array}{c}\text { Realisasi } \\
(\mathbf{R p})\end{array}$ & $\begin{array}{c}\text { Raio Efisiensi } \\
(\boldsymbol{\%})\end{array}$ & Kriteria \\
\hline 1 & 2012 & 4.907 .132 .200 & 2.508 .000 .707 & 195,66 & Tidak Efisien \\
2 & 2013 & 5.304 .256 .318 & 3.449 .307 .484 & 153,78 & Tidak Efisien \\
3 & 2014 & 3.425 .221 .136 & 5.056 .455 .794 & 67,74 & Tidak Efisien \\
4 & 2015 & 3.661 .254 .492 & 5.825 .614 .778 & 62,85 & Tidak Efisien \\
5 & 2016 & 4.897 .945 .353 & 7.829 .991 .234 & 62,55 & Tidak Efisien \\
\hline \multicolumn{7}{c}{ Rata-rata }
\end{tabular}

Sumber : Hasil Perhitungan (2018)

Dari tabel 5 terlihat bahwa rasio efisiensi pemungutan pendapatan asli daerah (PAD) di Kabupaten Maluku Tenggara Barat dari tahun 2012 - 2016 dikategorikan tidak efisien karena nilai rata-rata prosenatsenya $108,52 \%$ yang artinya biaya atau anggaran yang dikeluarkan atau diperuntukan untuk memungut penerimaan pajak daerah terlalu besar padahal tidak diikuti dengan kinerja pemungutan pajak daerah yang lebih baik.Namun dari tabel diatas terlihat bahwa trend rasio efisiensi terus mengalami penurunan dari waktu ke waktu yang artinya ada perbaikan sehingga menunjukan semakin efisien kinerja pemerintah daerah dalam melakukan pemungutan pajak daerah.

Berdasarkan hasil perhitungan diatas maka terdapat perbedaan bila dibandingkan dengan hasil penelitian yang dilakukan oleh Devy Octaviana S. (2103), Zainuddin (2016), Ryfal Yoduke et al (2015) dan Ismiranti M. Putri (2016). Rasio efisiensi dalam penelitian pemungutan pajak daerah di Kabupaten Maluku Tenggara Barat dikategorikan tidak 
efisien.Sedangkan di Provinsi Jawa Tengah (Devy Octaviana S., 2103), di Provinsi Maluku Utara (Zainuddin, 2016), di Kabupaten Bantul (Ryfal Yoduke et al, 2015) dan di Kota Surakarta (Ismiranti M. Putri, 2016) dikategorikan efisien.

\section{Derajat Kontribusi}

Hasil perhitungan kontribusi sub pajak daerah terhadap pajak daerah dapat dilihat pada tabel berikut ini :

\section{Tabel 6}

Derajat Kontribusi SubPajak Daerah terhadap Pajak Daerah Kabupaten Maluku Tenggara Barat Tahun 2012 - 2016

\begin{tabular}{|c|c|c|c|c|c|c|c|}
\hline \multirow{2}{*}{ No } & \multirow{2}{*}{ Sub Pajak Daerah } & \multicolumn{5}{|c|}{ Tahun dan Derajat Kontribusi } & \multirow{2}{*}{$\begin{array}{c}\text { Rata- } \\
\text { rata }(\%)\end{array}$} \\
\hline & & $\begin{array}{c}2012 \\
(\%)\end{array}$ & $\begin{array}{c}2013 \\
(\%)\end{array}$ & $\begin{array}{c}2014 \\
(\%)\end{array}$ & $\begin{array}{l}2015 \\
(\%)\end{array}$ & $\begin{array}{c}2016 \\
(\%)\end{array}$ & \\
\hline 1 & Pajak Hotel & 3,56 & 0,96 & 1,14 & 1,85 & 1,53 & 1,81 \\
\hline 2 & Pajak Restoran & 28,80 & 34,54 & 30,33 & 28,82 & 17,83 & 28,06 \\
\hline 3 & Pajak Hiburan & 1,25 & 0,64 & 0,58 & 1,03 & 0,51 & $\mathbf{0 , 8 0}$ \\
\hline 4 & Pajak Reklame & 12,37 & 7,48 & 7,53 & 8,00 & 6,31 & 8,33 \\
\hline 5 & Pajak Penerangan Jalan & 3,31 & 19,30 & 15,59 & 3,38 & 15,09 & 11,33 \\
\hline 6 & Pajak Mineral Bukan Logam dan Batuan & 46,35 & 28,80 & 33,65 & 46,96 & 51,46 & 41,44 \\
\hline 7 & Pajak Bumi dan Bangunan Perdesaan Perkotaan & - & - & 3,40 & 3,38 & 3,86 & 3,55 \\
\hline 8 & Bea Perolehan Ha katas Tanah dan Bangunan & 4,36 & 8,28 & 7,78 & 6,58 & 3,41 & 6,08 \\
\hline
\end{tabular}

Sumber : Hasil Perhitungan (2018)

Dari tabel 6 terlihat bahwa derajat kontribusi sub pajak daerah terhadap total pajak daerah di Kabupaten Maluku Tenggara Barat dari tahun 2012 - 2016 berfluktuasi setiap tahunnya. Pajak mineral bukan logam dan batuan sebagai sub pajak yang memberikan kontribusi terbesar terhadap pajak daerah dengan rata - rata 41,44\%. Secara absolut pajak mineral bukan logam dan batuan terus meningkat tetapi peningkatan total pajak lebih besar dibandingkan dengan peningkatan sub pajak ini sehingga derajat kontribusinya semakin menurun.Sesuai potensi sumber daya alam di Kabupaten Maluku Tenggara Barat memang banyak, tetapi sangat disayangkan karena fokus pemungutannya lebih banyak diarahkan kepada para kontraktor yang mengerjakan proyek-proyek fisik yang dibiayai oleh APBN maupun APBD, sedangkan wajib pajak yang menjual langsung kepada masyarakat (untuk membangun rumah) maupun pelaku usaha (membangun tempat usahanya) belum dipungut sehingga menjadi sumber penerimaan pajak mineral bukan logam dan batuan.

Berdasarkan hasil perhitungan diatas maka terdapat perbedaan bila dibandingkandenganhasil penelitian yang dilakukan oleh H. Mat Juri (2012) dan Reza Arditia (2012). Sebagai sumber urutan pertama sub pajak daerah di Kabupaten Maluku Tenggara Barat adalah pajak mineral bukan logam dan batuan sementara sumber urutan pertama di Kotamadya Samarinda (H Mat Juri, 2012) dan di Kotamadya Surabaya (Reza Arditia, 2012) adalah pajak penerangan jalan. 
Urutan selanjutnya sebagai sumber pajak daerah adalah pajak restoran dengan kontribusi rata-rata sebesar 28,06\%. Walaupun kontribusi terbesar kedua namun kontribusinya mengalami trend yang menurun hal ini mesti diwaspadai karena menunjukan tingkat ekonomi masyarakat yang terus menurun sehingga turut mempengaruhi pendapatan dari jenis usaha ini.

Berdasarkan hasil perhitungan diatas maka terdapat persamaan dengan hasil penelitian yang dilakukan oleh H. Mat Juri (2012) dan Reza Arditia (2012) yang menempatkan pajak restoran juga sebagai sumber urutan kedua pajak daerah untuk Kotamadya Samarinda ( H Mat Juri, 2012) dan Kotamadya Surabaya (Reza Arditia, 2012).

Urutan ketigayaitu pajak penerangan jalan dengan rata - rata kontribusi sebesar $11,33 \%$. Hal tersebut merupakan sebuah hal yang positif karena dengan terhubungnya hampir semua wilayah di Kabupaten MTB dengan aliran listrik dari PT. PLN seharusnya juga turut memberikan kontribusi yang baik karena secara otomatis akan bertambah jumlah wajib pajak penerangan jalan karena dengan membayar rekening listrik setiap bulannya maka mereka telah berkontribusi untuk jenis pajak penerangan jalan. Berdasarkan hasil perhitungan diatas maka terdapat perbedaan dengan hasil penelitian yang dilakukan oleh Reza Arditia (2012) yang menempatkan pajak hotel di Kotamadya Surabaya sebagai urutan ketiga sumber pendapatan pajak daerah.

\section{Efektifitas Pajak Daerah}

Berikut akan ditampilkan hasil perhitungan efektifitas pemungutan pajak daerah di Kabupaten Maluku Tenggara Barat :

Tabel 7

Efektifitas Pajak Daerah di Kabupaten Maluku Tenggara Barat Tahun 2012 - 2016

\begin{tabular}{c|c|c|c|c|c|}
\hline No & Tahun & Target (Rp) & Realisasi (Rp) & Efektifitas (\%) & Kriteria \\
\hline 1 & 2012 & 3.986 .256 .070 & 2.508 .000 .707 & 62,92 & Tidak Efektif \\
2 & 2013 & 4.328 .921 .800 & 3.449 .307 .484 & 79,68 & Kurang Efektif \\
3 & 2014 & 3.904 .700 .510 & 5.056 .455 .794 & 129,50 & Sangat Efektif \\
4 & 2015 & 6.665 .640 .612 & 5.825 .614 .778 & 87,40 & Kurang Efektif \\
5 & 2016 & 9.907 .280 .000 & 7.829 .991 .234 & 79,03 & Kurang Efektif \\
\hline \multicolumn{7}{|c|}{ Rata-rata } & $\mathbf{8 7 , 7 0}$ & KurangEfektif \\
\hline
\end{tabular}

Sumber :Hasil Perhitungan (2018)

Dari tabel 7 terlihat bahwa efektifitas pemungutan pajak daerah di Kabupaten Maluku Tenggara Barat dari tahun 2012-2016 berfluktuasi dengan rata-rata87,70\% atau kurang efektif. Capaian tertinggi tahun 2014 mencapai 129,50\%, penyebabnya adalah angka target yang ditetapkan lebih kecil dibandingkan dengan targetnyahal inidiakibatkan karena pada tahun ini digelarnya pemilihan legislative sehingga perkiraaan konstalasi politik yang akan memanas akan berdampak pada penerimaan pajak daerah padahal ekspektasi ini tidak terbukti justru ralisasinya besar sekali. Disamping itu terlihat bahwa belum adanya pola penetapan 
angka target yang tepat sehingga mengakibatkan efektifitas pajak daerah yang terus berfluktuasi. Berdasarkan hasil perhitungan diatas maka terdapat perbedaan dibandingkan dengan hasil penelitian yang dilakukan oleh H. Mat Juri (2012) dan Reza Arditia (2012).Dalam penelitian tentang efektifitas pemungutan pajak daerah di Kabupaten Maluku Tenggara Barat dikategorikan kurang efektif, sementara efektifitas pemungutan pajak daerah dalam penelitian di Kotamadya Samarinda (H Mat Juri, 2012) adalah efektif dan di Kotamadya Surabaya (Reza Arditia, 2012) adalah sangat efektif.

Dalam rangka menunjang pelaksanaan otonomi daerah di Kabupaten Maluku Tenggara Barat serta demi terwujudnya desentralisasi fiskal maka pemerintahan daerah sudah tentu akan selalu berusaha untuk mewujudkan kemandirian keuangan daerah. Tingkat kemandirian keuangan daerah yang besar menunjukan bahwa tingkat ketergantungan pemerintah daerah terhadap bantuan anggaran dari pemerintah pusat maupun pemerintah Provinsi Maluku melalui dana perimbangan semakin kecil pula. Dilain sisi, jika kemandirian keuangan daerah itu tinggi akan berdampak pada pelayanan publik yang lebih berkualitas serta terciptanya investasi jangka panjang dan meningkatnya pendapatan per kapita masyarakat. Perhatian serius dari pimpinan daerah terhadap manajemen serta pengelolaan pajak daerah dan sub pajak daerah di Kabupaten Maluku Tenggara Barat harus diperbaiki karena hasil penelitian menunjukan bahwa kinerja Badan Pendapatan Daerah Kabupaten Maluku Tenggara Barat dalam melakukan pemungutan pajak daerah masih termasuk kategori cukup efektifnamun rasio efisiensi pemungutan pajak daerah dikategorikan tidak efisien artinya anggaran yang diperuntukan terlalu besar dan tidak berbanding lurus dengan kinerja pemungutan pajak daerah sehingga akan berpengaruh pada kemandirian keuangan daerah karenaKabupaten Maluku Tenggara Barat masih termasuk kategori kabupaten yang memiliki tingkat ketergantungan yang sangat tinggi terhadap transfer dana atau anggaran dari pemerintah pusat maupun pemerintah provinsi yang artinya menunjukan kegagalan pemerintah daerah dalam mewujudkan cita-cita otonomi daerah.

\section{Efektifitas Sub Pajak Daerah}

Melalui analisis efektifitas dapat diketahui atau dapat memberikan gambaran seberapa besar realisasi sub pajak daerah terhadap target yang seharusnya tercapai pada kurun waktu $2012-2016$. 
Berikut adalah tabel efektifitas masing - masing komponen pajak daerah yang dipungut di Kabupaten Maluku Tenggara Barat :

Tabel 8

Efektifitas Pajak Hoteldi Kabupaten Maluku Tenggara Barat Tahun 2012 - 2016

\begin{tabular}{c|c|c|c|c|c}
\hline No & Tahun & Target $(\mathbf{R p )}$ & Realisasi (Rp) & Efektifitas (\%) & Kriteria \\
\hline 1 & 2012 & 60.000 .000 & 89.317 .813 & 148,86 & Sangat Efektif \\
2 & 2013 & 164.300 .000 & 33.298 .650 & 20,27 & Tidak Efektif \\
3 & 2014 & 79.500 .000 & 57.631 .050 & 72,49 & Tidak Efektif \\
4 & 2015 & 95.400 .000 & 107.761 .800 & 112,96 & Sangat Efektif \\
5 & 2016 & 120.000 .000 & 119.499 .470 & 99,58 & Cukup Efektif \\
\hline \multicolumn{7}{c}{ Rata-rata } \\
\hline
\end{tabular}

Sumber :Hasil Perhitungan (2018)

Dari tabel 8 terlihat bahwa efektifitas pemungutan pajak hotel di Kabupaten Maluku Tenggara Barat berfluktuasi tetapi masih dikategorikan sangat efektifdengan prosentase sebesar 221,32\%. Pada tabel diatas tahun 2013 penetapan target mencapai dua kali lipat dari nilai realisasi tahun sebelumnya, hal ini disebabkan diselenggarakannya kegiatan akbar yang berskala internasional di Kota Saumlaki sebagai Ibukota Kabupaten Maluku Tenggara Barat yaitu kegiatan Sail Indonesia dan Sail Saumlaki-Darwin yang melibatkan wisatawan mancanegara sehingga secara otomatis akan berdampak pada jumlah tamu yang akan memanfaatkan fasilitas dari hotel-hotel yang ada di Kota Saumlaki namun hal ini ternyata tidak berbanding lurus dengan nilai realisasinya.Berdasarkan hasil perhitungan diatas maka terdapat perbedaan bila dibandingkan dengan hasil penelitian yang dilakukan oleh Ratih U. Hidayanti (2008).Dalam penelitian tentang efektifitas pemungutan pajak hotel di Kab.MTB adalah sangat efektif sedangkan efektifitas pemungutan pajak hotel di Kota Banjarmasin (Ratih U. Hidayanti, 2008) adalah tidak efektif.Sedangkan terdapat persamaan antara hasil penelitian ini dengan hasil penelitian yang dilakukan oleh H. Mat Juri (2012) dimana efektifitas pemungutan pajak hotel di Kota Samarinda adalah cukup efektif.

Tabel 9

Efektifitas Pajak Restoran di Kabupaten Maluku Tenggara Barat Tahun 2012 - 2016

\begin{tabular}{c|c|c|c|c|c}
\hline No & Tahun & Target (Rp) & Realisasi (Rp) & Efektifitas (\%) & Kriteria \\
\hline 1 & 2012 & 1.956 .256 .070 & 722.188 .713 & 36,92 & Tidak Efektif \\
2 & 2013 & 1.525 .621 .800 & 1.191 .241 .287 & 78,08 & Kurang Efektif \\
3 & 2014 & 1.074 .590 .510 & 1.533 .474 .505 & 142,70 & Sangat Efektif \\
4 & 2015 & 1.289 .508 .612 & 1.678 .877 .338 & 130,20 & Sangat Efektif \\
5 & 2016 & 1.700 .000 .000 & 1.395 .871 .148 & 82,11 & Kurang Efektif \\
\hline \multicolumn{7}{|c}{ Rata-rata } & $\mathbf{9 4 , 0 0}$ & Cukup Efektif \\
\hline
\end{tabular}

Sumber :Hasil Perhitungan (2018)

Dari tabel 9 terlihat bahwa efektifitas pemungutan pajak restoran di Kabupaten Maluku Tenggara Barat adalah cukup efektifdengan prosentase $94,00 \%$, sebenarnya nilai rata-rata ini dipengaruhi oleh nilai realisasi pada tahun 2014 dan 2015 yang mencapai 142,70\% dan 130,20\%. Hal ini disebabkan karena pada tahun 2014 diselenggarakan pemilihan legislative 
dan pemilihan presiden yang tentunya diawali dengan masa kampanye yang pasti akan dihadiri oleh masa pendukung yang begitu banyak, menjadi sebuah kelasiman bahwa dalam rapat-rapat akbar dilapangan terbuka maupun kampanye dialogis pasti para calon akan menjamu pendukungnya dengan nasi bungkus sehingga hal ini tentunya berdampak pada nilai realisasi pajak restoran. Berdasarkan hasil perhitungan maka terdapat perbedaan dengan yang dilakukan oleh Ratih U. Hidayanti (2008), Ira Hardiana Kusuma W. (2005) dan Reza Arditia (2012).Dalam penelitian tentang efektifitas pemungutan pajak restoran di Kab.MTB adalah cukup efektif sedangkan efektifitas pemungutan pajak restoran di Kota Banjarmasin (Ratih U. Hidayanti, 2008), Ira Hardiana Kusuma W. (2005) di Kota Madiun dan Reza Arditia (2012) di Kota Surabaya adalah efektif. Selain itu hasil penelitian yang dilakukan di Kabupaten Sumbawa Barat (I Nyoman Sutama et al, 2017) dan Kota Surabaya (H. Mat Juri, 2012) dimana efektifitas pemungutan pajak restoran adalah sangat efektif.

Tabel 10

Efektifitas Pajak Hiburan di Kabupaten Maluku Tenggara Barat Tahun 2012 - 2016

\begin{tabular}{c|c|c|c|c|c}
\hline No & Tahun & Target (Rp) & Realisasi (Rp) & Efektifitas (\%) & Kriteria \\
\hline 1 & 2012 & 25.000 .000 & 31.328 .800 & 125,32 & Sangat Efektif \\
2 & 2013 & 75.000 .000 & 22.085 .750 & 29,45 & Tidak Efektif \\
3 & 2014 & 59.710 .000 & 29.334 .750 & 49,97 & Tidak Efektif \\
4 & 2015 & 70.452 .000 & 60.049 .888 & 85,24 & Kurang Efektif \\
5 & 2016 & 79.000 .000 & 39.994 .155 & 50,63 & Tidak Efektif \\
\hline \multicolumn{5}{c}{ Rata-rata } \\
\hline
\end{tabular}

Sumber :Hasil Perhitungan (2018)

Dari tabel 10 terlihat bahwa efektifitas pemungutan pajak hiburan di Kabupaten Maluku Tenggara Barat adalah tidak efektifdengan rata-rata efektifitas 67,95\% sehingga kinerja Pemerintah Kabupaten Maluku Tenggara Barat tidak berhasil dalam melakukan pemungutan jenis pajak hiburan.

Hal ini disebabkan karena belum pernah dilakukannya konser - konser musik baik oleh artis lokal maupun artis nasional, serta belum dibukanya bioskop sebagai sarana hiburan keluarga disamping itu belum tersedianya fasilitas karaoke keluarga turut mempengaruhi penerimaan daerah dari jenis pajak hiburan karena wajib pajak hiburan ini hanya bersumber dari karaoke atau pub yang dikhususkan untuk orang dewasa saja padahal tempat hiburan seperti karaoke atau pub ini pun sudah banyak yang tutup sebagai akibat dari sepinya jumlah tamu sehingga turut mempengaruhi jumlah realisasi pajak hiburan.Berdasarkan hasil perhitungan terdapat perbedaan dengan hasil penelitian yang dilakukan oleh H. Mat Juri (2012), Ratih U. Hidayanti (2008) dan Reza Arditia (2012).Pemungutan pajak hiburan di Kabupaten Maluku Tenggara Barat dari tahun 2009 - 2016 tidak efektif sedangkan efektifitas pemungutan pajak hiburan di Kota Samarinda (H. Mat Juri, 2012), di Kota Banjarmasin (Ratih U. Hidayanti, 2008), dan Kota Surabaya (Reza Arditia, 2012) adalah sangat efektif dan 
efektif.Hal ini menggambarkan potensi pajak hiburan sebagai sumber penerimaan pajak daerah.

Tabel 11

Efektifitas Pajak Reklame di Kabupaten Maluku Tenggara Barat Tahun 2012 - 2016

\begin{tabular}{c|c|c|c|c|c}
\hline No & Tahun & Target (Rp) & Realisasi (Rp) & Efektifitas (\%) & Kriteria \\
\hline 1 & 2012 & 750.000 .000 & 310.330 .000 & 41,38 & Tidak Efektif \\
2 & 2013 & 500.000 .000 & 257.970 .000 & 51,59 & Tidak Efektif \\
3 & 2014 & 506.900 .000 & 381.002 .800 & 75,16 & Kurang Efektif \\
4 & 2015 & 608.280 .000 & 465.975 .200 & 76,61 & Kurang Efektif \\
5 & 2016 & 608.280 .000 & 494.459 .500 & 81,29 & Kurang Efektif \\
\hline \multicolumn{5}{c}{ Rata-rata } \\
\hline
\end{tabular}

Sumber :Hasil Perhitungan (2018)

Dari tabel 11 terlihat bahwa efektifitas pemungutan pajak reklame di Kabupaten Maluku Tenggara Barat dikategorikan tidakefektif dengan prosentase rata-rata sebesar 65,21\%. Hal ini disebabkan karena belum tersedianya papan reklame yang disiapkan oleh pemerintah daerah padahal banyaknya kegiatan-kegiatan promosi yang dilakukan dengan memanfaatkan spanduk dan baliho baik oleh pihak swasta maupun politisi sehingga mempengaruhi rasio efektifitas pemungutan pajak reklame.

Hasil perhitungan diatas terdapat perbedaan dengan hasil penelitian yang dilakukan oleh Raymond R. Korengkeng (2017), H. Mat Juri (2012) dan Ratih U. Hidayanti (2008). Dalam penelitian mengenai efektifitas pemungutan pajak reklame hasilnya adalah tidak efektif sedangkan efektifitas pemungutan pajak reklame di Kabupaten Minahasa Utara (Raymond R. Korengkeng, 2017) adalah sangat efektif, di Kota Samarinda (H. Mat Juri, 2012)dan di Kota Banjarmasin (Ratih U. Hidayanti, 2008) adalah efektif sedangkan di Kota Surabaya (Reza Arditia, 2012) adalah cukup efektif.

Tabel 12

Efektifitas Pajak Penerangan Jalan di Kabupaten Maluku Tenggara Barat Tahun 2012-2016

\begin{tabular}{c|c|c|c|c|c}
\hline No & Tahun & Target (Rp) & Realisasi (Rp) & Efektifitas (\%) & Kriteria \\
\hline 1 & 2012 & 225.000 .000 & 83.046 .595 & 36,91 & Tidak Efektif \\
2 & 2013 & 500.000 .000 & 665.827 .547 & 133,17 & Sangat Efektif \\
3 & 2014 & 571.000 .000 & 788.301 .181 & 138,06 & Sangat Efektif \\
4 & 2015 & 471.000 .000 & 196.662 .824 & 41,75 & Tidak Efektif \\
5 & 2016 & 900.000 .000 & 1.181 .454 .141 & 131,27 & Sangat Efektif \\
\hline \multicolumn{7}{c}{ Rata-rata } & $\mathbf{9 6 , 2 3}$ & Cukup Efektif \\
\hline
\end{tabular}

Sumber :Hasil Perhitungan (2018)

Dari tabel 12 terlihat bahwa efektifitas pemungutan pajak penerangan jalan di Kabupaten Maluku Tenggara Barat termasuk kategori cukup efektif dengan prosentase sebesar 96,23\% dan hal ini berarti kinerja Pemerintah Kabupaten Maluku Tenggara Barat cukup berhasil dalam melakukan pemungutan jenis pajak daerah ini. Dari tabel diatas terlihat bahwa realisasi sub pajak penerangan jalan berfluktuasi bahkan pada tahun 2012 terlihat realisasi yang dicapai sangat kecil. Hal ini disebabkan karena pihak PT. PLN (Persero) Ranting Saumlaki 
tidak melakukan penyetoran hasil pungutan ke rekening kas daerah sehingga ketika dilakukan audit oleh BPK (Badan Pemeriksa Keuangan) maka menjadi temuan sehingga Badan Pemeriksa Keuangan langsung melakukan audit ke kantor mereka dan mereka diwajibkan untuk melakukan penyetoran kembali ke rekening kas daerah akhirnya nilai realisasi pada tahun 2013 dan tahun 2014 mengalami kenaikan yang sangat besar, begitupun hal yang sama terjadi pada tahun 2015 dan tahun 2016.

Selian itu dari tabel diatas juga terlihat bahwa terjadi kenaikan target yang sangat menonjol pada tahun 2013 hal ini disebabkan karena program Presiden Joko Widodo yang mewajibkan tersambungnya aliran listrik didaerah perbatasan mulai direalisasikan sehingga sebagian besar desa-desa yang ada di Kabupaten Maluku Tenggara Barat telah dialiri listrik dari PT. PLN (Persero) sehingga hal inilah yang dijadikan dasar untuk menaikan target sub pajak ini.Berdasarkan hasil perhitungan diatas maka terdapat perbedaan dengan hasil penelitian yang dilakukan oleh H. Mat Juri (2012) dan Reza Arditia (2012).Dalam penelitian tentang efektifitas pemungutan pajak penerangan jalan di Kab. MTB maka efektifitasnya adalah cukup efektif sedangkan rasio efektifitas pemungutan pajak penerangan jalan di Kota Samarinda (H. Mat Juri, 2012) adalah sangat efektif dan di Kota Surabaya (Reza Arditia, 2012) adalah efektif.

Tabel 13

Efektifitas Pajak Mineral Bukan Logam dan Batuan di Kabupaten Maluku Tenggara Barat Tahun $2012-2016$

\begin{tabular}{c|c|c|c|c|c}
\hline No & Tahun & Target (Rp) & Realisasi (Rp) & Efektifitas (\%) & Kriteria \\
\hline 1 & 2012 & 900.000 .000 & 1.162 .500 .886 & 129,17 & Sangat Efektif \\
2 & 2013 & 1.000 .000 .000 & 993.429 .000 & 99,34 & Cukup Efektif \\
3 & 2014 & 1.000 .000 .000 & 1.701 .706 .808 & 170,17 & Sangat Efektif \\
4 & 2015 & 3.300 .000 .000 & 2.735 .919 .200 & 82,91 & Kurang Efektif \\
5 & 2016 & 5.000 .000 .000 & 4.028 .995 .600 & 80,58 & Kurang Efektif \\
\hline \multicolumn{7}{|c|}{ Rata-rata } & $\mathbf{1 1 2 , 4 3}$ & Sangat Efektif \\
\hline
\end{tabular}

Sumber :Hasil Perhitungan (2018)

Dari tabel 13 terlihat bahwa efektifitas pemungutan pajak mineral bukan logam dan batuan di Kabupaten Maluku Tenggara Barat adalah sangat efektif dengan prosentase rata-rata sebesar $112,43 \%$ yang artinya kinerja Pemerintah Kabupaten Maluku Tenggara Barat berhasil dalam melakukan pemungutan pajak mineral bukan logam dan batuan. Walaupun rasio efektifitasnya sangat efektif namun dari tabel diatas terlihat bahwa realisasi lebih didominasi oleh tidak tercapainya target yang telah ditetapkan sebelumnya. Penyebabnya adalah realisasi ini sangat dipengaruhi oleh jumlah proyek fisik yang dikerjakan di Kabupaten Maluku Tenggara Barat artinya jika proyek fisik yang dikerjakan banyak maka nilai realisasi secara otomatis meningkat bila proyek fisik yang dikerjakan sedikit maka nilai realisasinya pun ikut menurun.Disamping itu fokus pemungutan lebih diarahkan kepada pekerjaan-pekerjaan fisik 
yang dibiayai oleh Anggaran Pendapatan dan Belanja Negara dan Anggaran Pendapatan dan Belanja Daerah Kabupaten sedangkan pekerjaan fisik yang dibiayai melalui dana Anggaran Pendapatan dan Belanja Daerah Provinsi tidak berhasil dipungut karena ketidak seriusan pimpinan dinas dalam melakukan pemungutan padahal nilai pajak dari pekerjaan-pekerjaan ini sudah dimasukan sebagai target, selain itu pengambilan material pajak mineral bukan logam dan batuan yang dijual kepada masyarakat umum pun tidak pernah dipungut.

Berdasarkan hasil perhitungan maka terdapat perbedaan dengan hasil penelitian yang dilakukan oleh H. Mat Juri (2012).Dalam penelitian rasio efektifitas pemungutan pajak mineral bukan logam dan batuan di Kabupaten Maluku Tenggara Barat adalah sangat efektif sedangkan rasio efektifitas pemungutan pajak mineral bukan logam dan batuan di Kota Samarinda (H. Mat Juri, 2012) adalah kurang efektif.

Tabel 14

Efektifitas Pajak Bumi dan Bangunan Perdesaan dan Perkotaan di Kabupaten Maluku Tenggara Barat Tahun 2009 - 2016

\begin{tabular}{c|c|c|c|c|c}
\hline No & Tahun & Target (Rp) & Realisasi (Rp) & Efektifitas (\%) & Kriteria \\
\hline 1 & 2012 & - & - & - & - \\
2 & 2013 & - & - & - & - \\
3 & 2014 & 314.000 .000 & 171.841 .880 & 54,73 & TidakEfektif \\
4 & 2015 & 471.000 .000 & 196.662 .824 & 41,75 & Tidak Efektif \\
5 & 2016 & 1.000 .000 .000 & 302.545 .788 & 30,25 & Tidak Efektif \\
\hline \multicolumn{7}{r}{ Rata-rata } \\
\hline
\end{tabular}

Sumber :Hasil Perhitungan (2018)

Dari tabel 14. diatas terlihat bahwa pajak bumi dan bangunan perdesaan dan perkotaan awalnya merupakan suatu jenis pajak pusat yang dipungut oleh pemerintah pusat melalui Direktorat Jenderal Pajak.Walaupun telah ditetapkan menjadi salah satu sumber pajak daerah namun sepanjang daerah kabupaten/kota belum ada pertauran daerah untuk mendukung pelaksanaan pemungutan maka pemungutannya tetap menjadi kewenangan pemerintah pusat sampai dengan tahun 2013.Dan pada tahun 2014 pajak bumi dan bangunan perdesaan dan perkotaan mulai dipungut di Kabupaten Maluku Tenggara Barat.

Dari tabel diatas menunjukan bahwa efektifitas pemungutan pajak bumi dan bangunan perdesaan dan perkotaan di Kabupaten Maluku Tenggara Barat dari tahun 2014 - 2016 adalah tidakefektif dengan prosentase rata-rata sebesar 42,25\% yang artinya kinerja Pemerintah Kabupaten Maluku Tenggara Barat tidak berhasil dalam melakukan pemungutan jenis pajak daerah ini.Hal ini disebabkan pajak bumi dan bangunan perdesaan dan perkotaan memang mempunyai wajib pajak yang riil dan bisa dihitung namun kelemahan selama ini adalah pencetakan surat pemberitahuan pajak terhutang (SPPT) oleh pemerintah daerah itu sangat terlambat, biasanya dicetak pada bulan Oktober - bulan November sehingga petugas pungut tidak punya waktu yang cukup untuk melakukan pemungutan selain itu wajib pajak pun 
kesulitan dalam membayar karena waktu pelunasan yang terlalu pendek. Sesuai peraturan daerah SPPT dibayarkan paling lama enam bulan sejak tanggal diterimanya surat ketetapan pajak daerah oleh wajib pajak namun kenyataannya tidak seperti itu karena keterlambatan pencetakan SPPT sehingga penagihan pun tidak maksimal. Selain itu pemerintah daerah masih terus melakukan pembaharuan-pembaharuan data karena banyaknya pendobolan wajib pajak sehingga turut mempengaruhi nilai pajak bumi dan bangunan perdesaan dan perkotaan. Berdasarkan hasil perhitungan maka rasio efektifitas pemungutan pajak bumi dan bangunan perdesaan dan perkotaan di Kabupaten Maluku Tenggara Barat adalah tidak efektif.Sampai dengan saat ini belum ada penelitian tentang efektifitas pemungutan pajak bumi dan bangunan perdesaan dan perkotaan, olehnya itu penelitian tentang efektifitas pemungutan pajak bumi dan bangunan perdesaan dan perkotaan di Kabupaten Maluku Tenggara Barat merupakan penelitian yang pertama sehingga belum bisa ditampilkan komparasi dengan hasil penelitian terdahulu.

Tabel 15

Efektifitas Bea Perolehan Hak atas Tanah dan Bangunandi Kabupaten Maluku Tenggara Barat Tahun $2012-2016$

\begin{tabular}{|c|c|c|c|c|c|}
\hline No & Tahun & Target (Rp) & Realisasi (Rp) & Efektifitas (\%) & Kriteria \\
\hline 1 & 2012 & 70.000 .000 & 109.287.900 & 156,13 & Sangat Efektif \\
\hline 2 & 2013 & 564.000 .000 & 285.455 .250 & 50,61 & Tidak Efektif \\
\hline 3 & 2014 & 300.000 .000 & 393.162 .820 & 131,05 & Sangat Efektif \\
\hline 4 & 2015 & 360.000 .000 & 383.705 .704 & 106,58 & Sangat Efektif \\
\hline 5 & 2016 & 500.000 .000 & 267.171 .432 & 53,43 & Tidak Efektif \\
\hline \multicolumn{4}{|c|}{ Rata-rata } & 99,56 & Cukup Efektif \\
\hline
\end{tabular}

Sumber :Hasil Perhitungan (2018)

Dari tabel 15 terlihat bahwa bea perolehan hak atas tanah dan bangunan awalnya merupakan suatu jenis pajak pusat yang dipungut oleh pemerintah pusat melalui Direktorat Jenderal Pajak. Walaupun telah ditetapkan menjadi salah satu sumber pajak daerah namun sepanjang daerah kabupaten/kota belum ada pertauran daerah untuk mendukung pelaksanaan pemungutan maka pemungutannya tetap menjadi kewenangan pemerintah pusat sampai dengan tahun 2010. Dan pada tahun 2011 bea perolehan hak atas tanah dan bangunan mulai dipungut di Kabupaten Maluku Tenggara Barat.

Dari tabel terlihat bahwa efektifitas pemungutan bea perolehan hak atas tanah dan bangunan di Kabupaten Maluku Tenggara Barat adalah cukup efektif dengan prosentase ratarata sebesar 99,56\% yang artinya kinerja Pemerintah Kabupaten Maluku Tenggara Barat cukup berhasil dalam melakukan pemungutan jenis pajak daerah ini. Hal ini disebabkan karena wajib pajak yang memperoleh bea perolehan hak atas tanah dan bangunan di Kabupaten Maluku Tenggara Barat wajib melaporkannya kepada pemerintah daerah namun dalam kenyataannya banyak transaksi yang tidak dilaporkan sehingga pemerintah daerah 
tidak mengetahuinya karena pajak daerah ini lebih bersifat insidentil. Berdasarkan hasil perhitungan maka rasio efektifitas pemungutan bea perolehan hak atas tanah dan bangunan di Kabupaten Maluku Tenggara Barat adalah cukup efektif. Sampai dengan saat ini belum ada penelitian tentang efektifitas pemungutan bea perolehan hak atas tanah dan bangunan, olehnya itu penelitian tentang efektifitas pemungutan bea perolehan hak atas tanah dan bangunan di Kabupaten Maluku Tenggara Barat merupakan penelitian yang pertama sehingga belum bisa ditampilkan komparasi dengan hasil penelitian terdahulu.

\section{KESIMPULAN}

Berdasarkan temuan, dapat disimpulkan bahwa rata-rata efisiensi pemungutan pajak daerah adalah $87,07 \%$ atau tidak efisien, sub pajak daerah yang berkontribusi pada total pajak daerah yang tertinggi adalah pajak mineral bukan logam dan batuan, pajak restoran dan pajak penerangan jalan, sedangkan yang terendah adalah pajak hiburan, pajak hotel dan pajak bumi dan bangunan perdesaan dan perkotaan. Rata-rata efektifitas pemungutan pajak daerah adalah 94,27\% atau cukup efektif dan rata-rata efektifitas sub pajak daerah, yaitu: pajak hotel adalah $221,32 \%$ atau sangat efektif, pajak restoran94\% atau cukup efektif, pajak hiburan 67,95\% atau tidak efektif, pajak reklame $65,21 \%$ atau tidak efektif, pajak penerangan jalan 96,23\% atau cukup efektif, mineral bukan logam dan batuan $112,43 \%$ atau sangat efektif, pajak bumi dan bangunan perdesaan dan perkotaan $42,25 \%$ atau tidak efektif dan bea perolehan hak atas tanah dan bangunan adalah 99,56\% atau cukup efektif.

\section{DAFTAR PUSTAKA}

Avian Nur Andianto et al, 2017. Analisis Efektifitas dan Efisiensi Penerimaan Pajak Daerah Kota Malang Tahun 2013 - 2015. Seminar Nasional\& Call For Paper FEB Unikama 2017.

Devy Octaviana S., 2103. Analisis Efektifitas dan Efisiensi Pajak Daerah Serta Kontribusinya Terhadap PAD Di Propinsi Jawa Tengah Tahun 2008 - 2012.

H. Mat Juri, 2012. Analisis Kontribusi Pajak Daerah dan Retribusi Daerah Terhadap Pendapatan Asli Daerah (PAD) Kota Samarinda. Jurnal Eksis, Vol. 8 No. 1, Maret 2012.

Ira Hardiana Kusuma W., 2005. Analisis Efektifitas dan Efisiensi Pemungutan Pajak Hotel dan Pajak Restoran Dalam Rangka Meningkatkan PAD Di Kota Madiun Tahun 2000 2004.

Ismiranti M. Putri, 2016. Analisis Efektifitas, Efisiensi dan Kontribusi Pajak Daerah dan Retribusi Daerah Terhadap Peningkatan PAD Di Kota Surakarta Tahun 2009-2014.

I Gede Oka Dhananjaya B et al, 2015. Perbandingan Efektifitas dan Kontribusi Pajak Daerah Pada PAD Di Kota Denpasar dan Kabupaten Badung. 
I Nyoman Sutama et al, 2017. Analisis Efisiensi, Efektifitas dan Kontribusi Pajak Hotel dan Pajak Restoran Terhadap PAD Di Kabupaten Sumbawa Barat Tahun 2011-2016. Jurnal Ekonomi dan Bisnis, Vol. 14 Tahun 2017.

Martha Marice Koibur, 2015. Analisis Kontribusi Pajak Daerah Terhadap Pendapatan Asli Daerah (PAD) Di Kota Sorong.

Mahmudi, SE., M.Si., 2010. Analisis Laporan Keuangan Pemerintah Daerah (Panduan Bagi Eksekutif, DPRD dan Masyarakat dalam Pengambilan Keputusan Ekonomi, Sosial dan Politik). Penerbit : STIM YKPN, Yogyakarta.

Pratiwi DK., 2002. Strategi Peningkatan Penerimaan Pajak Bumi dan Bangunan (PBB) : Studi Kasus Di Kabupaten Klaten. Jurnal Kebijakan dan Administrasi Publik UGM. Vol. 6 Tahun 2002.

Peraturan Pemerintah Republik Indonesia Nomor 27 Tahun 1980 Tentang Penggolongan Bahan - Bahan Galian

Permendagri No. 21 Tahun 2011 Tentang Perubahan Kedua Atas Permendagri No. 13 Tahun 2006 Tentang Pedoman Pengelolaan Keuangan Daerah

Peraturan Daerah Kabupaten Maluku Tenggara Barat Nomor 02 Tahun 2011 Tentang Pajak Daerah

Ratih U. Hidayanti, 2008. Analisis Efektifitas dan Efisiensi Pajak Daerah Dalam Upaya Meningkatkan PAD Kota Banjarmasin Kalimantan Selatan Tahun 2003-2007.

Ryfal Yoduke et al, 2015. Analisis Efektifitas dan Efisiensi Pajak Daerah Serta Kontribusi Terhadap PAD Di Kabupaten Bantul Tahun 2009-2014. Jurnal Akuntansi, Vol. 3 Tahun 2015.

Reza Arditia, 2012. Analisis Kontribusi dan Efektifitas Pajak Daerah Sebagai Sumber PAD Kota Surabaya.

Raymond R. Korengkeng et al, 2017. Analisis Potensi, Efektifitas, Efsisensi dan Kontribusi Pajak Reklame Terhadap Penerimaan Pajak Daerah Di Kabupaten Minahasa Utara. Jurnal Riset Akuntansi Going Concern 12, 2017

Undang-undang Nomor 9 Tahun 2015 Tentang Perubahan Kedua Atas Undang-undang Nomor 23 Tahun 2014 Tentang Pemerintahan Daerah.

Undang-undang Nomor 28 Tahun 2009 Tentang Pajak Daerah dan Retribusi Daerah.

Wempy Banga, Prof. Dr. M.Si (2017). Administrasi Keuangan Negara dan Daerah (Konsep, Teori dan Fenomena di Era Otonomi Daerah). Penerbit : Ghalia Indonesia

Yaneka Julistiana et al, 2012 Analisis Efisiensi dan Efektifitas Penerimaan PAD Kabupaten Klungkung.

Zainuddin, 2016 Efisiensi, Efektifitas dan Kontribusi Pajak Daerah Terhadap PAD Provinsi Maluku Utara. Jurnal Ilmu Ekonomi dan Sosial, Vol. 7 Tahun 2016.

www.keuda.kemendagri.go.id

www.djpk.go.id

www.hukumonline.com 